\title{
In Vitro Activities of Kissorphin, a Novel Hexapeptide KiSS-1 Derivative, in Neuronal Cells
}

\author{
Nathaniel G. N. Milton \\ Department of Human and Health Sciences, School of Life Sciences, University of Westminster, London W1W 6UW, UK \\ Correspondence should be addressed to Nathaniel G. N. Milton, n.milton@westminster.ac.uk
}

Received 31 March 2012; Accepted 11 June 2012

Academic Editor: Dorothy Gietzen

Copyright ( $) 2012$ Nathaniel G. N. Milton. This is an open access article distributed under the Creative Commons Attribution License, which permits unrestricted use, distribution, and reproduction in any medium, provided the original work is properly cited.

The primary products of the metastasis-suppressor KiSS-1 gene are the kisspeptin (KP) peptides that stimulate gonadotrophinreleasing-hormone (GnRH) release via GPR-54 receptor activation. Recent studies have suggested that the KP-10 peptide also activates neuropeptide FF (NPFF) receptors. The aim of the current study was to determine the activities of the KiSS-1 derivative kissorphin (KSO), which contains the first six amino acids of the KP-10 peptide, is C-terminally amidated, and shares amino acid similarities with the biologically active NPFF 3-8 sequence. The KSO peptide inhibited forskolin-stimulated cyclic adenosine monophosphate (cAMP) production in ND7/23 neuroblastoma cells via an action that could be inhibited by the NPFF receptor antagonist RF9. Release of GnRH by LA-N-1 neuroblastoma cells was not altered by the KSO peptide. In ND7/23 neuroblastoma cells, the KSO peptide was able to reduce forskolin neuroprotection against $\mathrm{H}_{2} \mathrm{O}_{2}$ toxicity. The KSO peptide was also able to prevent prostaglandin E2-induced apoptosis in rat cortical neurons. The NPFF receptor antagonist RF9 could inhibit these actions of the KSO peptide in oxidative stress and apoptosis models. In conclusion, the kissorphin peptide, comprising the amino acid sequence Tyr-Asn-Trp-Asn-Ser-Phe- $\mathrm{NH}_{2}$, has NPFF-like biological activity without showing any GnRH releasing activity and inhibits forskolin-activated cAMP release.

\section{Introduction}

Recent studies have shown that kisspeptin (KP) peptides can activate the two neuropeptide FF (NPFF) receptors, NPFFR1 (GPR-147) and NPFFR2 (GPR-74) [1-3]. These actions of KP peptides can be blocked by NPFF receptor antagonists including RF9 [4]. The NPFF peptide is a ligand for both these receptors [5-7], and the biologically active NPFF 38 form [8] shows amino acid sequence similarities to KP peptides (Table 1).

The KP peptides themselves play a central role in the hypothalamic-pituitary-gonadal (HPG)-axis by acting on gonadotrophin-releasing hormone $(\mathrm{GnRH})$ neurons to activate GnRH release [9]. The KP peptides are encoded by the metastasis-suppressor KiSS-1 gene and are ligands for the GPR-54 receptor [1, 10-12]. A range of KP peptides are found in vitro and in vivo with the largest 54 amino acid form corresponding toresidues 68-121 of the KiSS-1 encoded pre-
pro-KP [10]. Shorter derivatives of KP comprising the Cterminal 14, 13, and 10 amino acids have also been found in tissues and corresponding to residues 108-121, 109-121, and 112-121 of the KiSS-1 encoded pre-pro-KP $[10,13]$. Biological activity of KP peptides requires the KP 112-121 sequence with an amidated C-terminus $[10,13,14]$.

The biological activities of NPFF include antiopioid $[8$, 15], analgesic [16], anorexigenic [17, 18], cardiovascular $[19,20]$, adipocyte [21], and immune cell [22] effects. The biological activities of NPFF involve an action that can be measured as inhibition of forskolin-stimulated cyclic adenosine monophosphate (cAMP) production and are mediated via activation of the NPFFR1 or NPFFR2 receptors [23-25].

Cleavage of KP peptides to remove the amidated Cterminal tripeptide Leu-Arg-Phe- $\mathrm{NH}_{2}$ of the $\mathrm{KP}$ sequence by matrix metalloproteinase (MMP) enzymes abolishes the activation of GPR-54 by KP peptides [26]. However, the 
TABLE 1: Comparison of kisspeptin, kissorphin, and NPFF sequences.

\begin{tabular}{lcccccccccccccc}
\hline Kisspeptin-13 & Leu & Pro & Asn & Tyr & Asn & Trp & Asn & Ser & Phe & Gly & Leu & Arg & Phe & $\mathrm{NH}_{2}$ \\
Kisspeptin-10 & & & & Tyr & Asn & Trp & Asn & Ser & Phe & Gly & Leu & Arg & Phe & $\mathrm{NH}_{2}$ \\
Kissorphin & & & & Tyr & Asn & Trp & Asn & Ser & Phe & $\mathrm{NH}_{2}$ & & \\
Neuropeptide FF & & \multirow{2}{*}{ Phe } & Leu & Phe & Gln & Pro & Gln & Arg & Phe & $\mathrm{NH}_{2}$ & & \\
& & & & $*$ & $\dagger$ & $*$ & $\dagger$ & & $*$ & & & & \\
\end{tabular}

${ }^{*}$ Ring structure aminoacid; ${ }^{\dagger}$ uncharged polar aminoacid.

resultant peptides have a C-terminal glycine residue that could be alpha-amidated [27] and C-terminal alpha amidation is a feature of many biologically active neuropeptides. As such the MMP cleaved KP peptides could have an alternative biological activity. In view of the similarities between KP and NPFF sequences it is possible that the hexapeptide fragment of KP-10 containing residues 1-6 with a C-terminally amidated phenylalanine residue could have NPFF-like activity. The aim of the study has been to determine if the KP derivative Tyr-Asn-Trp-Asn-Ser-Phe$\mathrm{NH}_{2}$, termed kissorphin (KSO), has biological activity and to determine whether KSO peptides have NPFF-like activities in neuronal cell culture-based assays.

\section{Materials and Methods}

2.1. Materials. Synthetic NPFF, KP, and KSO peptides were obtained from Bachem. Mouse neuroblastoma $\mathrm{x}$ rat neuron hybrid ND7/23 [28] and human LA-N-1 neuroblastoma [29] cell lines were obtained from the Health Protection Agency, Cell Culture Collection. Rat cortical neurons and cell culture media were obtained from Invitrogen. The cAMP EIA kits and other test chemicals were obtained from Sigma-Aldrich.

2.2. Cell Cultures. Mouse neuroblastoma $\mathrm{x}$ rat neuron hybrid $\mathrm{ND} 7 / 23$ and human LA-N-1 neuroblastoma cells were routinely grown in a $5 \% \mathrm{CO}_{2}$ humidified incubator at $37^{\circ} \mathrm{C}$ in a $1: 1$ mixture of Dulbecco's modified Eagle's medium and HAM's F12 with Glutamax (Invitrogen) supplemented with $10 \%$ foetal calf serum (FCS), $1 \%$ nonessential amino acids, penicillin (100 units $/ \mathrm{ml})$, and streptomycin $(100 \mathrm{mg} / \mathrm{ml})$ [30-32]. Primary cultures of rat cortical neurons were prepared from cryopreserved rat cortex neurons [33] isolated from day-18 Fisher 344 rat embryos and cultured according to the supplier instructions in Neurobasal/B27 medium.

\subsection{Inhibition of Forskolin Stimulated cAMP Assays. ND7/23} cells were plated onto 24-well plates in normal growth medium and cultured overnight. The medium was replaced with serum-free medium containing $100 \mu \mathrm{M}$ IBMX on the day of the experiment for $2 \mathrm{~h}$ prior to the addition of test compounds $[3,34]$. Cells were then treated with medium alone (control) or medium containing $10 \mu \mathrm{M}$ forskolin and $100 \mu \mathrm{M}$ IBMX and varying doses $(10 \mathrm{nM}-100 \mu \mathrm{M})$ of the synthetic NPFF, KP, or KSO peptides. Cells were then incubated at $37^{\circ} \mathrm{C}$ for a total of $30 \mathrm{~min}$, after which the medium was aspirated and replaced with a $1 \mathrm{ml}$ of $0.1 \mathrm{M} \mathrm{HCl}$ and incubated for $15 \mathrm{~min}$ to stop the reaction and lyse the cells.
Cell lysates were centrifuged to remove cellular debris and cAMP levels in the supernatant determined. The ir-cAMP levels were determined using a direct enzyme immunoassay kit according to the manufacturers instructions. Samples and standards were acetylated prior to incubation with anticAMP antibody and cAMP-alkaline phosphatase conjugate.

2.4. GnRH Release Assay. LA-N-1 cells were plated onto 24-well plates in normal growth medium and cultured overnight. On the day of experiment, cells were then treated with medium alone (control) or medium containing varying doses $(10 \mathrm{nM}-10 \mu \mathrm{M})$ of the synthetic NPFF, KP, or KSO peptides. Cells were then incubated at $37^{\circ} \mathrm{C}$ for a total of 2 hours, after which the medium was aspirated for determination of GnRH levels. The immunoreactive (ir) GnRH was measured by EIA using synthetic biotinyl-GnRHI, GnRH-I standards, primary anti-GnRH antibody coated immunoplates, and detection with streptavidin labeled HRP and TMB substrate.

2.5. Forskolin Neuroprotection against Hydrogen Peroxide $\left(\mathrm{H}_{2} \mathrm{O}_{2}\right)$ Toxicity. ND7/23 cells were plated onto 96-well plates in normal growth medium and cultured overnight. On the day of the experiment cells were treated with combinations of media alone (control), $\mathrm{H}_{2} \mathrm{O}_{2}(250 \mu \mathrm{M})$ to induce toxicity, forskolin $(10 \mu \mathrm{M})$ to protect against $\mathrm{H}_{2} \mathrm{O}_{2}$ toxicity [35], and $10 \mu \mathrm{M}$ NPFF, KP, or KSO peptides. Cells were incubated for 2 hours prior to determination of cell viability.

2.6. Prostaglandin- $E_{2}\left(P G E_{2}\right)$ Toxicity. Rat cortical neurons were plated onto 96 -well plates in normal growth medium. On the day of the experiment, cells were treated with media alone (control), $\mathrm{PGE}_{2}(25 \mu \mathrm{M})$ to induce toxicity [36], and either $10 \mu \mathrm{M}$ NPFF, KP, or KSO peptides. Cells were incubated for 24 hours prior to determination of cell viability.

2.7. Cell Viability. After treatment with test peptides or drugs and incubation for the appropriate time the viability was determined by either trypan blue dye exclusion with at least 100 cells counted per well or by MTT reduction [37]. For MTT reduction determination, after incubation with test substances MTT (10 $\mu \mathrm{l}: 12 \mathrm{mM}$ stock) was added and cells incubated for a further 4 hours. Cell lysis buffer $(100 \mu \mathrm{l} /$ well; 20\% (v/v) SDS, 50\% (v/v) N,N-dimethylformamide, and $\mathrm{pH}$ 4.7) was added and after repeated pipetting to lyse cells the MTT formazan product formation was determined by 


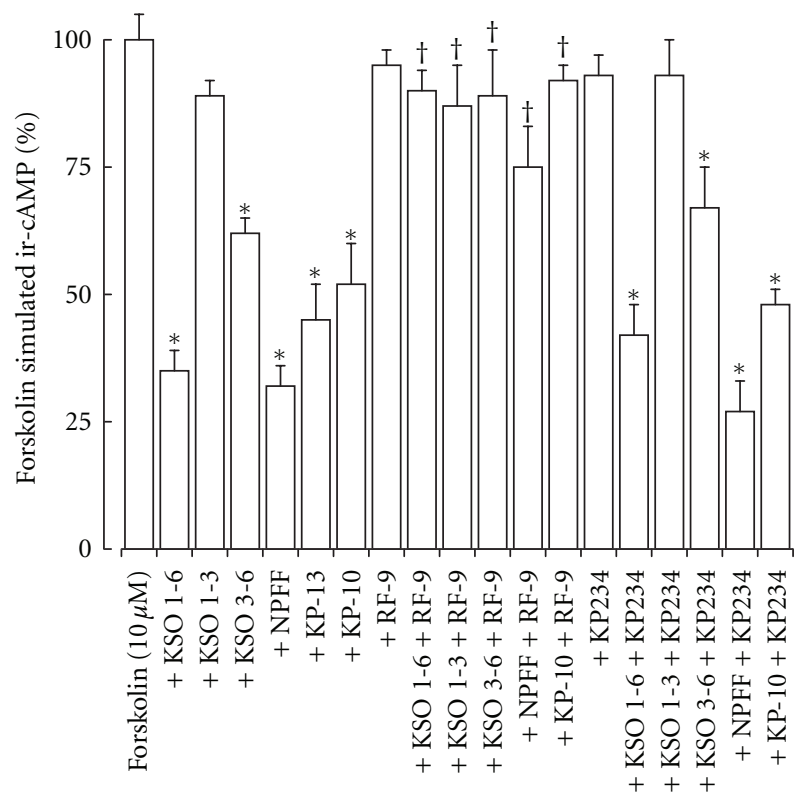

Figure 1: Effect of KSO, NPFF, and KP peptides on forskolinstimulated ir-cAMP release from ND-7/23 cells. Cells were exposed to forskolin with KSO, NPFF, or KP peptides for 30 min prior to termination of the reaction with $0.1 \mathrm{M} \mathrm{HCl}$. The effects of the NPFF receptor antagonist RF9 and the GPR-54 antagonist KP234 on KSO, NPFF, or KP peptide inhibition of forskolin-stimulated ir-cAMP release were also determined. Levels of ir-cAMP in the cell lysates were measured by EIA. Results are mean $\pm \operatorname{sem}(n=8) .{ }^{*} P<0.05$ versus forskolin alone; ${ }^{\dagger} P<0.05$ versus $\mathrm{KSO}$, NPFF, or KP peptide alone; one-way ANOVA.

measurement of absorbance change at $570 \mathrm{~nm}$. Control levels in the absence of test substances were taken as $100 \%$, and the absorbance in the presence of cells lysed with Triton X-100 at the start of the incubation period with test substances was taken as $0 \%[38]$.

2.8. Data Analysis. All data are expressed as means \pm s.e.m. For irGnRH measurements levels in samples were determined from a standard curve using synthetic GnRH-I as the standard. For cytotoxicity experiments data are expressed as $\%$ dead (trypan blue stained) cells or \% control cells (MTT reduction). The significance of differences between data was evaluated by one-way analysis of variance (ANOVA). A $P$ value of $<0.05$ was considered statistically significant.

\section{Results}

3.1. Effect of KSO Peptides on NPFF-Like Biological Activity. The NPFF-like biological activity was determined by measurement of forskolin-stimulated ir-cAMP release in response to KSO, KP, and NPFF peptides. The KSO peptides containing residues 1-6 and 3-6 significantly inhibited forskolin stimulated ir-cAMP release from ND-7/23 cells (Figure 1), whilst the KSO 1-3 fragment had no effect. The NPFF, KP-10, and KP-13 peptides also significantly inhibited forskolin stimulated ir-cAMP release, which could

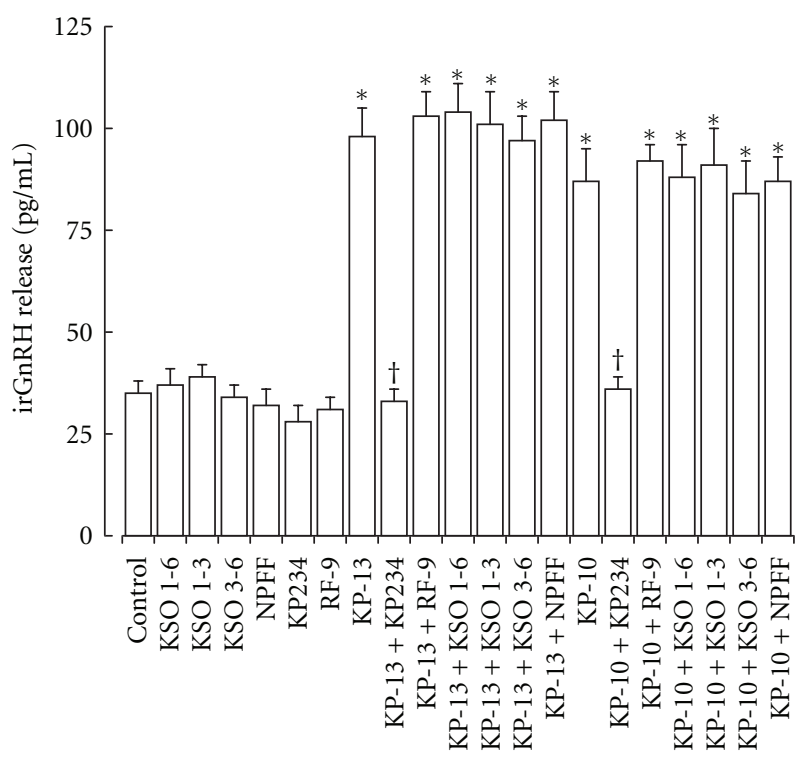

FIGURE 2: Effect of KSO, NPFF, and KP peptides on irGnH release from LA-N-1 neuroblastoma cells. Cells were exposed to KSO, NPFF, KP, the NPFF receptor antagonist RF9, and the GPR-54 antagonist KP234 for 2 hours. Levels of irGnRH in the media were measured by EIA. Results are mean \pm s.e.m. $(n=8)$. ${ }^{*} P<0.05$ versus control (media alone); ${ }^{\dagger} P<0.05$ versus KP peptide alone; one-way ANOVA.

be antagonized by the NPFF receptor antagonist RF-9 [4] but not the GPR-54 receptor antagonist KP234 [39]. The RF-9 and KP234 had no effect on forskolin-stimulated ir-cAMP release.

3.2. Effect of KSO Peptides on KP-Like Biological Activity. The KP-like biological activity was determined by measurement of irGnRH release in response to KSO, KP, and NPFF peptides. The KSO peptides containing residues 1-6, 13 and 3-6 had no effect on irGnRH release from LA-N1 neuroblastoma cells (Figure 2). The KP-10 and KP-13 peptides both stimulated a significant increase in $\mathrm{irGnRH}$ release, which could be antagonized by the GPR-54 receptor antagonist KP234 [39] but not the NPFF receptor antagonist RF-9 [4]. The KSO peptides had no effect on KP stimulated irGnRH release. NPFF, RF-9, and KP234 had no effect on irGnRH release.

3.3. Effect of KSO Peptides on $\mathrm{H}_{2} \mathrm{O}_{2}$ and $P G E_{2}$ Neurotoxicity. The effects of KSO peptides were tested in two models of neurotoxicity. In the $\mathrm{H}_{2} \mathrm{O}_{2}$-stimulated-toxicity model the KSO 1-6 and 3-6 peptides, plus NPFF and KP-10 peptides, inhibited the forskolin protection against $\mathrm{H}_{2} \mathrm{O}_{2}$ toxicity in ND-7/23 cells (Figure 3). These effects could be reversed by the NPFF receptor antagonist RF-9 but not the GPR-54 antagonist KP234. In the $\mathrm{PGE}_{2}$-induced-toxicity model the KSO 1-6 and 3-6 peptides, plus NPFF and KP-10 peptides, were able to reduce the $\mathrm{PGE}_{2}$ toxicity (Figure 4 ). These effects could be reversed by the NPFF receptor antagonist RF-9 but not the GPR-54 antagonist KP234. 


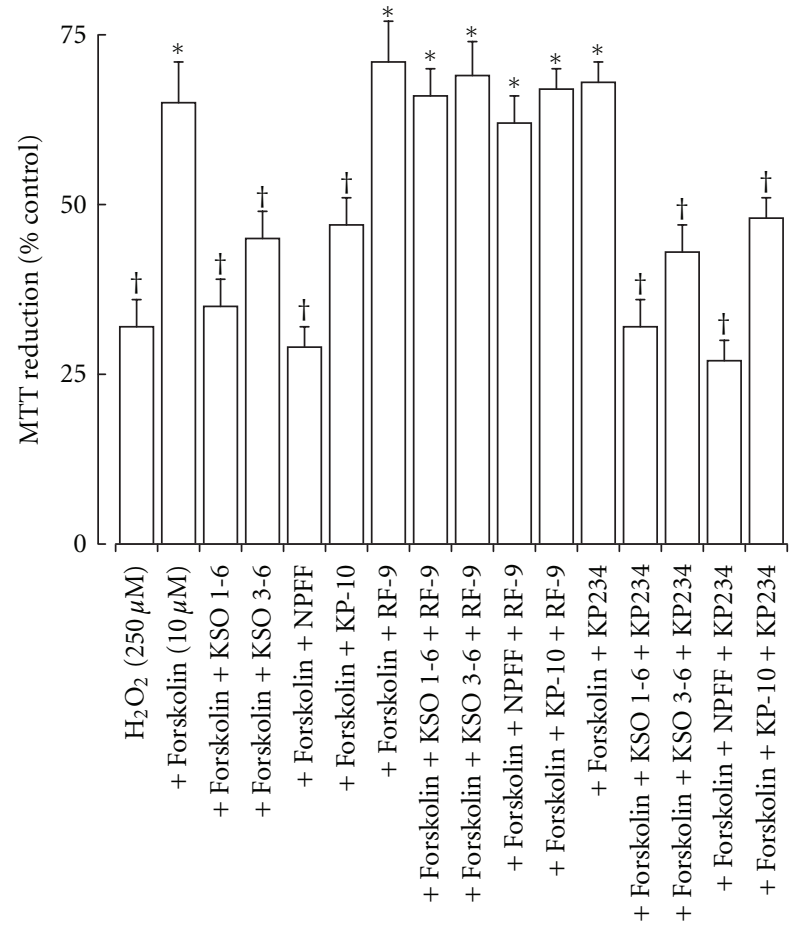

Figure 3: Effect of KSO, NPFF, and KP peptides on forskolin prevention of $\mathrm{H}_{2} \mathrm{O}_{2}$ toxicity in ND-7/23 cells. Cells were exposed to $\mathrm{H}_{2} \mathrm{O}_{2}$ either alone or in the presence of forskolin with KSO, NPFF, or KP peptides for 2 hours prior determination of cell viability by MTT reduction. The effects of the NPFF receptor antagonist RF9 and the GPR-54 antagonist KP234 were also determined. Results are expressed as \% Control MTT reduction (mean \pm sem; $n=8$ ). ${ }^{*} P<0.05$ versus $\mathrm{H}_{2} \mathrm{O}_{2}$ alone; ${ }^{\dagger} P<0.05$ versus $\mathrm{H}_{2} \mathrm{O}_{2}$ plus forskolin; one-way ANOVA.

\section{Discussion}

The results show that the KSO peptide has biological activity in neuronal cell models that can be antagonized by the NPFF receptor antagonist RF-9 [4] but not the GPR-54 receptor antagonist KP234 [39]. The actions of KSO involve inhibition of stimulated cAMP release and are similar to documented effects for both NPFF $[23,40]$ and KP peptides [1-3] in vitro. The NPFF receptors respond to a number of RF-amide containing peptides [41], but this is the first demonstration of a response to an SF-amide peptide. The contribution of NPFFR1 and NPFFR2 receptors to the observed effects has not been tested. Both these receptors react with NPFF [42] and KP peptides [2, 3], and it is likely that KSO peptides will act on both receptor types. The cross-reactivity of NPFF with some KP antibodies [43] suggests shared tertiary structure similarity as well as sequence similarity exists. The ability of NPFF, KP, and KSO peptides to act in similar neuronal models suggests that the KSO sequence represents the region of KP with NPFF similarity. The distribution of NPFF receptors [23, 44-47] suggests that the main effects of KSO peptides is likely to be restricted and there may also be species differences. The specificity of the NPFF antagonist RF-9 $[3,4]$ used in this study does not rule out actions via other related receptors.

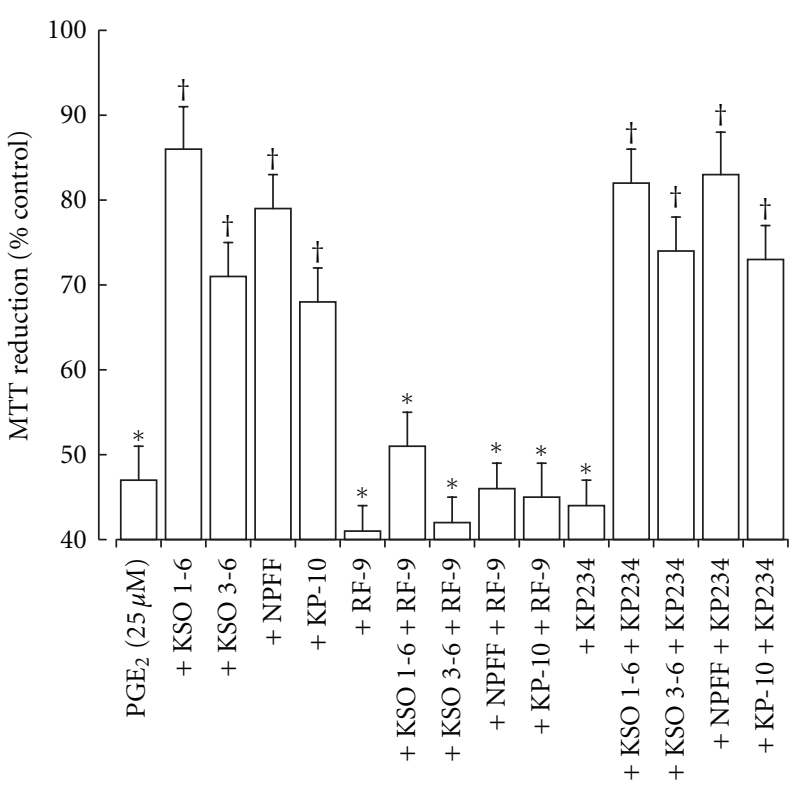

Figure 4: Effect of KSO, NPFF, and KP peptides on $\mathrm{PGE}_{2}$ toxicity in rat cortical neurons. Cells were exposed to $\mathrm{PGE}_{2}$ either alone or in the presence of KSO, NPFF, or KP peptides for 24 hours prior determination of cell viability by MTT reduction. The effects of the NPFF receptor antagonist RF9 and the GPR-54 antagonist KP234 were also determined. Results are expressed as \% Control MTT reduction (mean \pm s.e.m.; $n=8$ ). ${ }^{*} P<0.05$ versus control; ${ }^{\dagger} P<0.05$ versus $\mathrm{PGE}_{2}$ alone; one-way ANOVA.

However, the actions of KSO are shared with NPFF and KP peptides, suggesting that a common feature that RF9 can block mediates the effects. Cell lines overexpressing NPFFR1 and NPFFR2 receptors have been used to determine receptor-binding affinities and cAMP inhibition by NPFF related peptides $[6,24,42]$ and could be employed to confirm KSO interactions with NPFF receptors.

The ability of MMP enzymes to cleave KP-10 in vitro [26] to yield the KSO sequence, with an extra C-terminal Gly residue that can be amidated [27], raises the possibility that KSO-like peptides could be generated both in vitro and in vivo. The observations that KP peptides down regulate the expression of MMP enzymes [48] suggest that this action may be limited by release of KP peptides. However, there are conditions where MMP enzymes are elevated, and since the effects of KP peptides are at the level of protein expression rather than activity, there may be conditions where KSO-like peptides could be generated. The KSO sequence and MMP cleavage sites in the KiSS-1 precursor protein are shared between the human $[10,13]$ and rat forms [49]. It cannot be excluded that the actions of KP-10 and KP-13 in the cell models tested are due to generation of KSO-like peptides.

The ability of KSO peptides to prevent $\mathrm{PGE}_{2}$ toxicity in rat cortical neurons raises the possibility that KSO peptides could be neuroprotective; however, the reversal of forskolin neuroprotection by KSO peptides suggests that any neuroprotective properties may be model specific. The expression of appropriate NPFF or related receptors that KSO peptides can bind to and activate responses from may 
also be key for neuroprotective activity. In a recent study the KP peptides including the KSO 1-6 fragment were shown to be neuroprotective against amyloid peptides via a receptor-independent mechanism [50]. The results with the reversal of forskolin neuroprotection suggest that in vivo the KSO peptides could have multiple actions and therefore not show measurable neuroprotective properties. The requirement for doses in the $\mu \mathrm{M}$ range suggests that the effects being observed may not be seen at physiological concentrations of endogenous KSO peptides.

The lack of GnRH releasing activity of the KSO peptides is in agreement with previous studies [26]. The KSO peptide used in the present study has an amidated C-terminus instead of the glycine residue used in the Takino et al. [26] study, however, this has not added a GnRH releasing bioactivity.

\section{Conclusions}

The present study has identified a biological activity as an inhibitor of stimulated cAMP release for the KSO peptides with the sequences Tyr-Asn-Trp-Asn-Ser-Phe- $\mathrm{NH}_{2}$ and TrpAsn-Ser-Phe- $\mathrm{NH}_{2}$, which can be antagonized by an NPFF receptor antagonist. These actions are seen in neuronal cell models based on human, mouse, and rat cells, suggesting that the action is not species specific.

\section{Conflict of Interests}

N. G. N. Milton is named as the inventor on patent applications held by the University of Roehampton for the use of Kissorphin peptides to treat Alzheimer's disease, CreutzfeldtJakob disease, or diabetes mellitus (PCT/EP2011/058213); under the University's rules he could benefit financially if the patent is exploited.

\section{References}

[1] H. R. Kirby, J. J. Maguire, W. H. Colledge, and A. P. Davenport, "International Union of Basic and Clinical Pharmacology. LXXVII. Kisspeptin receptor nomenclature, distribution, and function," Pharmacological Reviews, vol. 62, no. 4, pp. 565578, 2010.

[2] Y. Lyubimov, M. Engstrom, S. Wurster, J. M. Savola, E. R. Korpi, and P. Panula, "Human kisspeptins activate neuropeptide FF2 receptor," Neuroscience, vol. 170, no. 1, pp. 117-122, 2010.

[3] S. Oishi, R. Misu, K. Tomita et al., "Activation of neuropeptide FF receptors by kisspeptin receptor ligands," ACS Medicinal Chemistry Letters, vol. 2, no. 1, pp. 53-57, 2011.

[4] F. Simonin, M. Schmitt, J. P. Laulin et al., "RF9, a potent and selective neuropeptide FF receptor antagonist, prevents opioid-induced tolerance associated with hyperalgesia," Proceedings of the National Academy of Sciences of the United States of America, vol. 103, no. 2, pp. 466-471, 2006.

[5] H. Y. T. Yang, W. Fratta, E. A. Majane, and E. Costa, "Isolation, sequencing, synthesis, and pharmacological characterization of two brain neuropeptides that modulate the action of morphine," Proceedings of the National Academy of Sciences of the United States of America, vol. 82, no. 22, pp. 7757-7761, 1985.
[6] N. Vyas, C. Mollereau, G. Chevé, and C. R. McCurdy, "Structure-activity relationships of neuropeptide FF and related peptidic and non-peptidic derivatives," Peptides, vol. 27, no. 5, pp. 990-996, 2006.

[7] P. Panula, A. A. Aarnisalo, and K. Wasowicz, "Neuropeptide FF, a mammalian neuropeptide with multiple functions," Progress in Neurobiology, vol. 48, no. 4-5, pp. 461-487, 1996.

[8] S. Gicquel, H. Mazarguil, C. Desprat et al., "Structure-activity study of neuropeptide FF: contribution of N-terminal regions to affinity and activity," Journal of Medicinal Chemistry, vol. 37, no. 21, pp. 3477-3481, 1994.

[9] V. M. Navarro and M. Tena-Sempere, "Neuroendocrine control by kisspeptins: role in metabolic regulation of fertility," Nature Reviews Endocrinology, vol. 8, no. 1, pp. 40-53, 2012.

[10] M. Kotani, M. Detheux, A. Vandenbogaerde et al., "The metastasis suppressor gene KiSS-1 encodes kisspeptins, the natural ligands of the orphan $\mathrm{G}$ protein-coupled receptor GPR54," Journal of Biological Chemistry, vol. 276, no. 37, pp. 34631-34636, 2001.

[11] A. I. Muir, L. Chamberlain, N. A. Elshourbagy et al., "AXOR12, a novel human $\mathrm{G}$ protein-coupled receptor, activated by the peptide KiSS-1," Journal of Biological Chemistry, vol. 276, no. 31, pp. 28969-28975, 2001.

[12] T. Ohtaki, Y. Shintani, S. Honda et al., "Metastasis suppressor gene KiSS-1 encodes peptide ligand of a G-protein-coupled receptor," Nature, vol. 411, no. 6837, pp. 613-617, 2001.

[13] M. Bilban, N. Ghaffari-Tabrizi, E. Hintermann et al., "Kisspeptin-10, a KiSS-1/metastin-derived decapeptide, is a physiological invasion inhibitor of primary human trophoblasts," Journal of Cell Science, vol. 117, no. 8, pp. 1319-1328, 2004.

[14] E. Gutiérrez-Pascual, J. Leprince, A. J. Martínez-Fuentes et al., "In vivo and in vitro structure-activity relationships and structural conformation of kisspeptin-10-related peptides," Molecular Pharmacology, vol. 76, no. 1, pp. 58-67, 2009.

[15] F. Kersanté, J. Y. Wang, J. C. Chen, C. Mollereau, and J. M. Zajac, "Anti-opioid effects of neuropeptide FF receptors in the ventral tegmental area," Neuroscience Letters, vol. 488, no. 3, pp. 305-309, 2011.

[16] I. Quelven, A. Roussin, O. Burlet-Schiltz et al., "Dissociation of pharmacological pro- and anti-opioid effects by neuropeptide FF analogs," European Journal of Pharmacology, vol. 449, no. 1-2, pp. 91-98, 2002.

[17] T. Murase, H. Arima, K. Kondo, and Y. Oiso, "Neuropeptide FF reduces food intake in rats," Peptides, vol. 17, no. 2, pp. 353-354, 1996.

[18] M. A. Cline, W. Nandar, and J. O. Rogers, "Central neuropeptide FF reduces feed consumption and affects hypothalamic chemistry in chicks," Neuropeptides, vol. 41, no. 6, pp. 433-439, 2007.

[19] Q. Fang, N. Li, T. N. Jiang, Q. Liu, Y. L. Li, and R. Wang, "Pressor and tachycardic responses to intrathecal administration of neuropeptide FF in anesthetized rats," Peptides, vol. 31, no. 4, pp. 683-688, 2010.

[20] L. Prokai, A. D. Zharikova, A. Juhasz, and K. Prokai-Tatrai, "Cardiovascular effects of neuropeptide FF antagonists," Peptides, vol. 27, no. 5, pp. 1015-1019, 2006.

[21] I. Lefrère, P. De Coppet, J. C. Camelin et al., "Neuropeptide $\mathrm{AF}$ and FF modulation of adipocyte metabolism. Primary insights from functional genomics and effects on $\beta$-adrenergic responsiveness," Journal of Biological Chemistry, vol. 277, no. 42, pp. 39169-39178, 2002.

[22] M. Minault, J. C. Lecron, S. Labrouche, G. Simonnet, and J. Gombert, "Characterization of binding sites for neuropeptide 
FF on T lymphocytes of the Jurkat cell line," Peptides, vol. 16, no. 1, pp. 105-111, 1995.

[23] N. A. Elshourbagy, R. S. Ames, L. R. Fitzgerald et al., "Receptor for the pain modulatory neuropeptides FF and AF is an orphan G protein-coupled receptor," Journal of Biological Chemistry, vol. 275, no. 34, pp. 25965-25971, 2000.

[24] J. A. Bonini, K. A. Jones, N. Adham et al., "Identification and characterization of two $G$ protein-coupled receptors for neuropeptide FF," Journal of Biological Chemistry, vol. 275, no. 50, pp. 39324-39331, 2000.

[25] M. Kotani, C. Mollereau, M. Detheux et al., "Functional characterization of a human receptor for neuropeptide FF and related peptides," British Journal of Pharmacology, vol. 133, no. 1, pp. 138-144, 2001.

[26] T. Takino, N. Koshikawa, H. Miyamori et al., "Cleavage of metastasis suppressor gene product KiSS-1 protein/metastin by matrix metalloproteinases," Oncogene, vol. 22, no. 30, pp. 4617-4626, 2003.

[27] E. J. Husten and B. A. Eipper, "Purification and characterization of PAM-1, an integral membrane protein involved in peptide processing," Archives of Biochemistry and Biophysics, vol. 312, no. 2, pp. 487-492, 1994.

[28] J. N. Wood, S. J. Bevan, P. R. Coote et al., "Novel cell lines display properties of nociceptive sensory neurons," Proceedings of the Royal Society B, vol. 241, no. 1302, pp. 187-194, 1990.

[29] R. C. Seeger, S. A. Rayner, and A. Banerjee, "Morphology, growth, chromosomal pattern, and fibrinolytic activity of two new human neuroblastoma cell lines," Cancer Research, vol. 37, no. 5, pp. 1364-1371, 1977.

[30] F. W. Kluxen, A. Hülster, M. Droste, and T. Pfeuffer, "The expression of a novel $\mathrm{Ca}^{2+} / \mathrm{CaM}$ stimulated adenylyl cyclase activity in the neuroblastoma cell line Lan-1 is regulated by cell density," Brain Research, vol. 740, no. 1-2, pp. 169-174, 1996.

[31] N. G. N. Milton, "Homocysteine inhibits hydrogen peroxide breakdown by catalase," The Open Enzyme Inhibition Journal, vol. 1, pp. 34-41, 2008.

[32] M. Calissano and D. S. Latchman, "Cell-specific regulation of the pro-survival Brn-3b transcription factor by microRNAs," Molecular and Cellular Neuroscience, vol. 45, no. 4, pp. 317-323, 2010.

[33] S. C. Schock, K. S. Jolin-Dahel, P. C. Schock et al., "Development of dissociated cryopreserved rat cortical neurons in vitro," Journal of Neuroscience Methods, vol. 205, no. 2, pp. 324-333, 2012.

[34] F. Talmont, L. Moulédous, L. Piedra-Garcia et al., "Pharmacological characterization of the mouse NPFF2 receptor," Peptides, vol. 31, no. 2, pp. 215-220, 2010.

[35] H. Kamata, C. Tanaka, H. Yagisawa, and H. Hirata, "Nerve growth factor and forskolin prevent $\mathrm{H}_{2} \mathrm{O}_{2}$-induced apoptosis in PC12 cells by glutathione independent mechanism," Neuroscience Letters, vol. 212, no. 3, pp. 179-182, 1996.

[36] T. Takadera, H. Yumoto, Y. Tozuka, and T. Ohyashiki, "Prostaglandin E2 induces caspase-dependent apoptosis in rat cortical cells," Neuroscience Letters, vol. 317, no. 2, pp. 61-64, 2002.

[37] N. G. N. Milton, N. P. Mayor, and J. Rawlinson, "Identification of amyloid- $\beta$ binding sites using an antisense peptide approach," NeuroReport, vol. 12, no. 11, pp. 2561-2566, 2001.

[38] N. G. N. Milton, "Amyloid- $\beta$ phosphorylation," in Cell Biology Protocols, J. R. Harris, J. M. Graham, and D. Rickwood, Eds., pp. 364-368, John Wiley \& Sons, Chichester, UK, 2006.

[39] A. K. Roseweir, A. S. Kauffman, J. T. Smith et al., "Discovery of potent kisspeptin antagonists delineate physiological mechanisms of gonadotropin regulation," Journal of Neuroscience, vol. 29, no. 12, pp. 3920-3929, 2009.

[40] C. Mollereau, C. Gouardères, Y. Dumont et al., "Agonist and antagonist activities on human NPFF2 receptors of the NPY ligands GR231118 and BIBP3226," British Journal of Pharmacology, vol. 133, no. 1, pp. 1-4, 2001.

[41] G. M. Anderson, "Pituitary actions of RFamide peptides: a critique of the evidence," The Open Neuroendocrinology Journal, vol. 4, pp. 51-63, 2011.

[42] M. Findeisen, D. Rathmann, and A. G. Beck-Sickinger, "Structure-activity studies of RFamide peptides reveal subtype-selective activation of neuropeptide FF1 and FF2 receptors," ChemMedChem, vol. 6, no. 6, pp. 1081-1093, 2011.

[43] N. Iijima, K. Takumi, N. Sawai, and H. Ozawa, "An immunohistochemical study on the expressional dynamics of kisspeptin neurons relevant to $\mathrm{GnRH}$ neurons using a newly developed anti-kisspeptin antibody," Journal of Molecular Neuroscience, vol. 43, no. 2, pp. 146-154, 2011.

[44] V. Dupouy, A. Puget, A. Eschalier, and J. M. Zajac, "Species differences in the localization of neuropeptide FF receptors in rodent and lagomorph brain and spinal cord," Peptides, vol. 17, no. 3, pp. 399-405, 1996.

[45] M. L. Nieminen, A. Brandt, P. Pietilä, and P. Panula, "Expression of mammalian RF-amide peptides neuropeptide FF (NPFF), prolactin-releasing peptide (PrRP) and the PrRP receptor in the peripheral tissues of the rat," Peptides, vol. 21, no. 11, pp. 1695-1701, 2000.

[46] Z. Zeng, T. P. McDonald, R. Wang, Q. Liu, and C. P. Austin, "Neuropeptide FF receptor 2 (NPFF2) is localized to pain-processing regions in the primate spinal cord and the lower level of the medulla oblongata," Journal of Chemical Neuroanatomy, vol. 25, no. 4, pp. 269-278, 2003.

[47] C. Gouardéres, A. Puget, and J. M. Zajac, "Detailed distribution of neuropeptide FF receptors (NPFF1 and NPFF2) in the rat, mouse, octodon, rabbit, guinea pig, and marmoset monkey brains: a comparative autoradiographic study," Synapse, vol. 51, no. 4, pp. 249-269, 2004.

[48] Y. Teng, M. Liu, and J. K. Cowell, “"Functional interrelationship between the WASF3 and KISS1 metastasisassociated genes in breast cancer cells," International Journal of Cancer, vol. 129, no. 12, pp. 2825-2835, 2011.

[49] Y. Terao, S. Kumano, Y. Takatsu et al., "Expression of KiSS-1, a metastasis suppressor gene, in trophoblast giant cells of the rat placenta," Biochimica et Biophysica Acta, vol. 1678, no. 2-3, pp. 102-110, 2004.

[50] N. G. N. Milton, A. Chilumuri, E. Rocha-Ferreira, A. N. Nercessian, and M. Ashioti, "Kisspeptin prevention of amyloid- $\beta$ peptide neurotoxicity in vitro," ACS Chemical Neuroscience, 2012. 

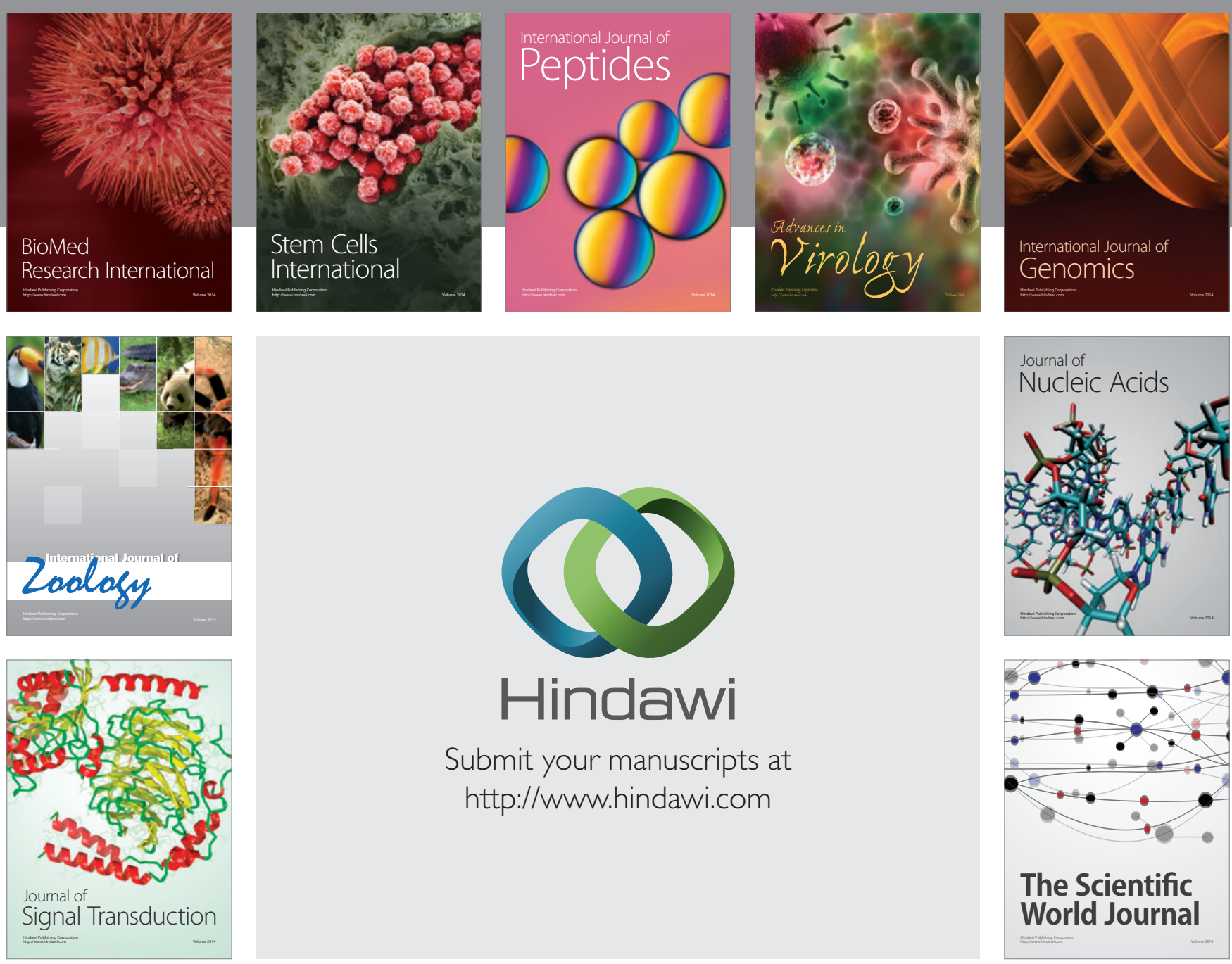

Submit your manuscripts at

http://www.hindawi.com
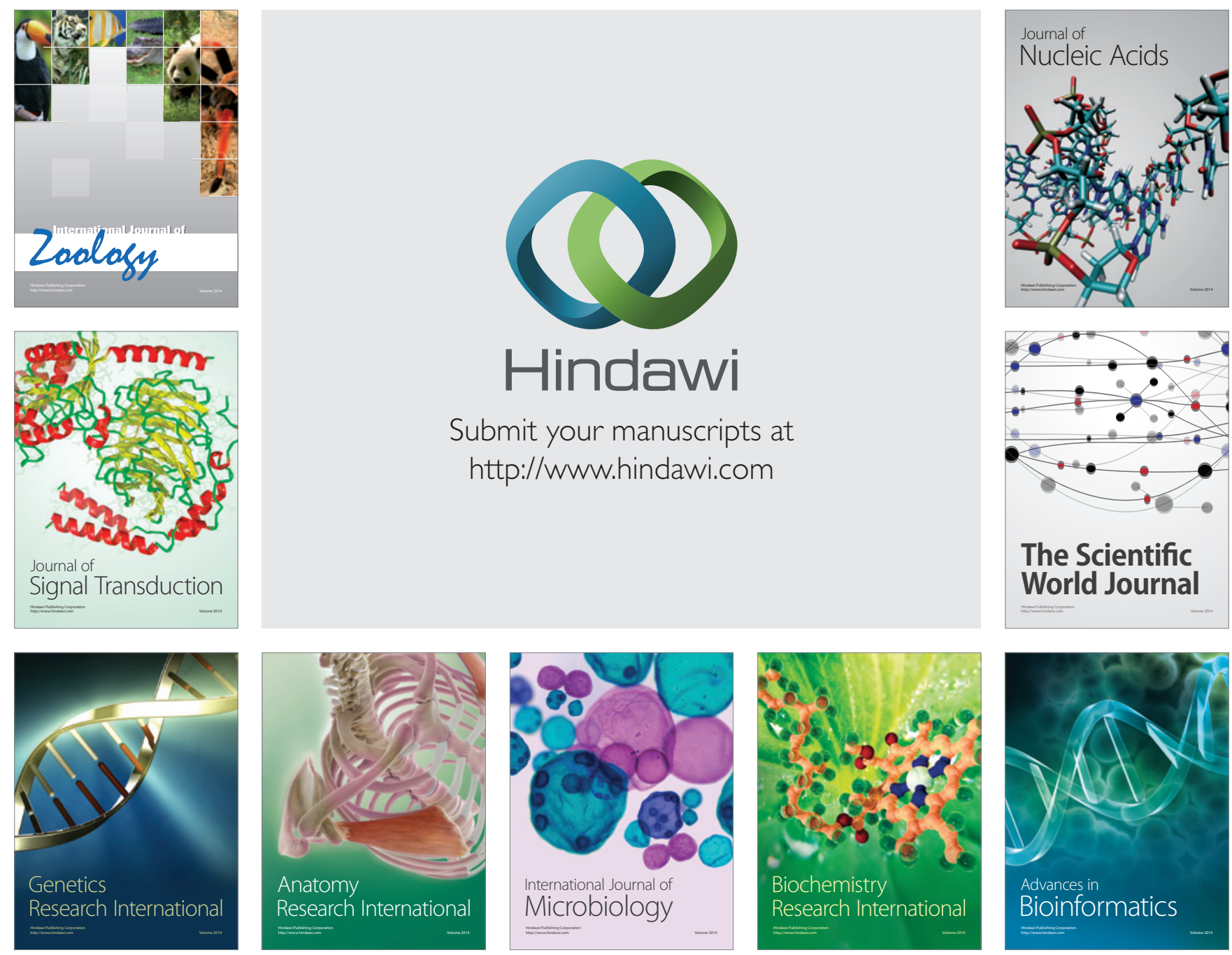

The Scientific World Journal
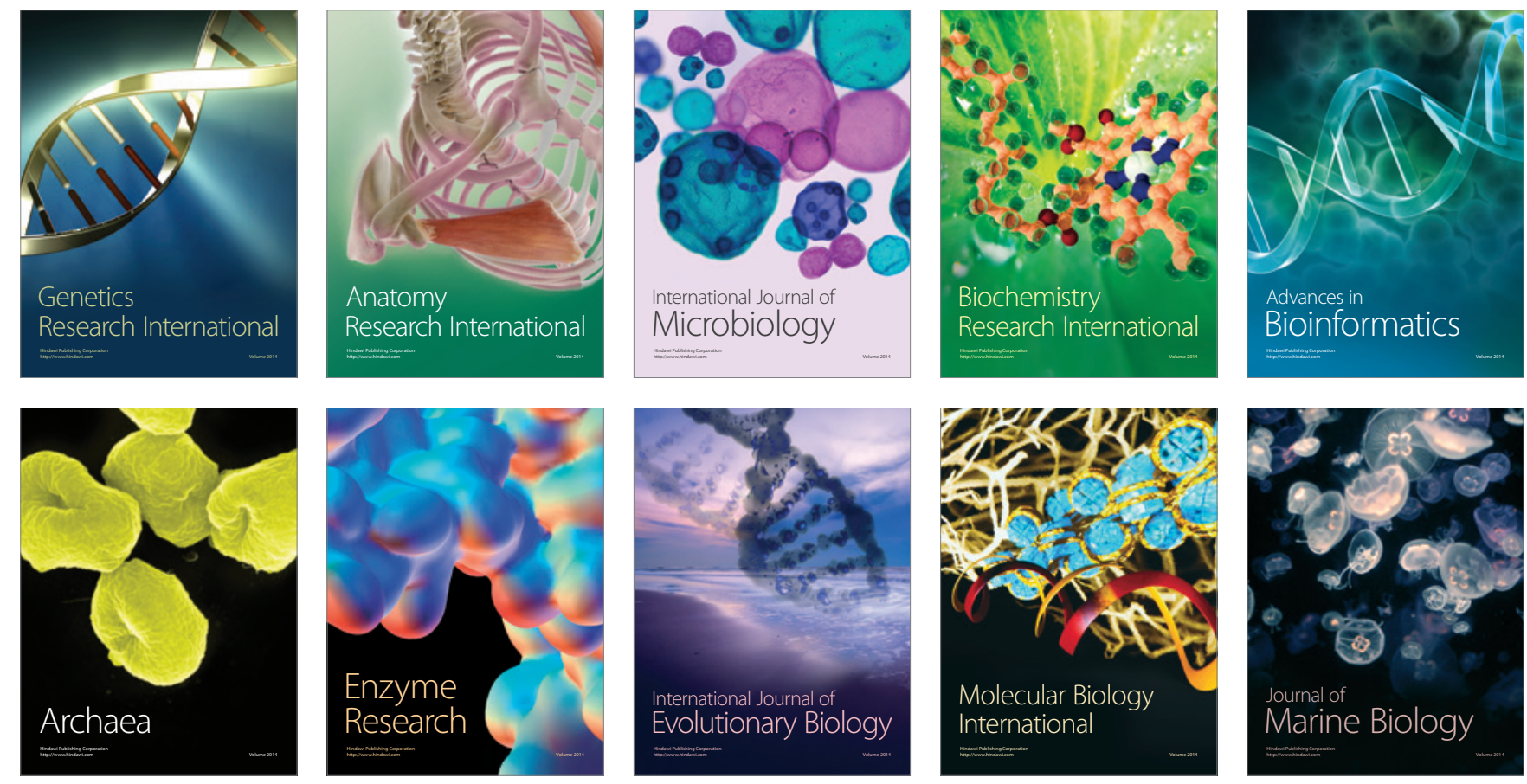